\title{
REVOLUTIONS IN CHEMICAL ENGINEERING THROUGH THE DEVELOPMENT OF MATERIALS SCIENCE AND PRODUCT DESIGN FOR SUSTAINABLE ENERGY AND FUTURE APPLICATIONS
}

\author{
Eny Kusrini ${ }^{1,2 *}$, Sutrasno Kartohardjono ${ }^{1}$ \\ ${ }^{1}$ Department of Chemical Engineering, Faculty of Engineering, Universitas Indonesia, Kampus \\ UI Depok, Depok, 16424, Indonesia \\ ${ }^{2}$ Tropical Renewable Energy Center, Faculty of Engineering, Universitas Indonesia, Kampus UI \\ Depok, Depok, 16424, Indonesia
}

Materials science is an interdisciplinary engineering and science area covering the nature of materials and their applications in various fields of science, chemistry, physics, mathematics, biology, engineering, applied physics, chemical engineering, mechanical engineering, civil, and electricity. Its main focus is to explore the key relation between the structure, properties and application of matter. Therefore, it is one of the broadest and most active areas in chemical engineering, involving the discovery, evaluation and manipulation of useful material properties of different substances.

To date, materials science has been expanding the array of materials that have unique characteristics and are useful for the development and fabrication of desirable, imaginative, and revolutionary new products. Related research has been contributing to great progress towards a sustainable future based on clean energy generation, through the development of ethanol production using syngas fermentation, transmission and distribution, the storage of electrical and chemical energy, energy efficiency, and better energy management systems. These advances aim to fulfill the widescale growing demand for energy in both developed and developing countries. Clean energy policy is also associated with the concerns about the detrimental effects of fossil fuels on the environment. Such environmental concerns have been at the forefront of limiting technological advances in various industrial sectors, prompting the intensive utilization of membrane filters, sensors and catalysts. In addition to the climate change associated with gas emissions from automobiles and factories, access to clean water, consumption of raw materials in the refining and separation processes of fossil fuels, and waste management have become important environmental issues, which scientists and engineers are actively trying to solve for present-day and future life. Innovative biocompatible materials, for instance, have improved the quality of life and lengthened people's life spans. Chemical engineers have been at the forefront of these advances, creating applicable materials in the fields of biochemistry, thermodynamics and supercritical, nanomaterials and nanotechnology, chemical engineering management, separation and purification, renewable energy, water and waste treatment, food technology and pharmaceuticals, catalysts, chemical reactions, and engineering process systems.

To address the abovementioned issues, the $1^{\text {st }}$ International Symposium of Indonesian Chemical Engineering 2018 (ISIChem), with the main theme of "Chemical Engineering," was held from October 4-6, 2018, at Kyriad Bumiminang Hotel, Padang, Sumatra Barat, Indonesia. The symposium, which was organized by Asosiasi Pendidikan Tinggi Teknik Kimia Indonesia (APTEKIM), facilitated researchers, academics and industry practitioners to present and discuss

\footnotetext{
${ }^{*}$ Corresponding author's email: ekusrini@che.ui.ac.id, Tel: +62-21-7863516 ext. 204, Fax: +62-21-7863515 Permalink/DOI: https://doi.org/10.14716/ijtech.v10i3.3173
} 
their research in scientific forums in the field of chemical engineering and to share their knowledge. In the symposium, twenty papers from various countries across the globe, including Japan, Libya, Taiwan, Malaysia and Indonesia, were presented. This Insight discusses the latest advances in materials science, which may boost the transition to a more sustainable environment and energy systems.

In this issue of the International Journal of Technology, we provide coverage of the 1st International Symposium of Indonesian Chemical Engineering 2018 (ISIChem). At the symposium, the participants updated the current trends in new materials and approaches to the reuse of energy and waste, providing a space for discussion focusing on the methodology, technology, and empirical work of tropical renewable energy. Publishing information on the conference via traditional printed media, however, takes time and, for several reasons, the discussion presented might remain unknown to a wider audience. In this current special issue of the International Journal of Technology, we would therefore like to present the discussions in the form of research papers, thereby making them available to a wider readership. We are pleased to present 20 papers and, through the availability of the published materials, enrich and extend the ISIChem symposium reports.

The first paper, written by E.O. Ningrum, S. Sakohara, T. Gotoh, Suprapto and N. Humaidah, investigates the transition and ion-adsorption behavior of DMAAPS gel and polymer in nitrate, chloride and sulfate solutions. An aqueous solution of poly (DMAAPS) exhibited an upper critical solution temperature (UCST) in salt solution, and with an increase in salt concentration, the UCST first rose, and then fell. The adsorption behavior of cation in nitrate, chloride and sulphate solution was found to be a strong function of the valence, with the order of adsorption being $\mathrm{Zn}^{2+}>\mathrm{Ni}^{2+}>\mathrm{Na}^{+}, \mathrm{K}^{+}$. The number of ions adsorbed onto the DMAAPS gel in various salt solutions with a common cation of $\mathrm{Na}^{+}, \mathrm{K}^{+}$and $\mathrm{Zn}^{2+}$ showed a tendency in the order of $\mathrm{NO}^{3-}>\mathrm{Cl}^{-}>\mathrm{SO}_{4}{ }^{2-}$.

The second paper, written by T. Iswanto, N. Hendrianie, M. Shovitri, A. Altway, and T. Widjaja, investigates the microbial method in terms of a fungal and bacterial mixture, producing satisfying results in the degradation of lignin and pectin in coffee pulp waste, with more than $99 \%$ removal of these compounds. Due to the highest cellulose concentration (of more than $80 \%$ ) in the pretreated coffee pulp waste, two co-cultures, AN:TR (1:1) and BS:TR (2:1), were chosen for the subsequent hydrolysis process. The hydrolysis of pretreated CPW using A. niger and $\mathrm{T}$. viride, with the addition of surfactant, resulted in a higher yield of reducing sugar than without surfactant. The highest yield of reducing sugar resulted from the pretreated CPW by AN:TR (1:1), hydrolyzed by a co-culture of AN:TV (2:1) with a PEG 4000 addition of $20.69 \%$.

The third paper, written by A.N. Istyami, R. Purwadi, M.T.A.P. Kresnowati, T. Prakoso and T.H. Soerawidjaja, investigates immobilization methods for frangipani crude latex. Immobilization was successfully achieved by encapsulation in a calcium alginate matrix, producing a lower, yet homogenous, degree of lipolysis. This enables the recycling of lipase, although in limited frequencies, although the process is susceptible to contamination of a broken matrix. Free lipases produce a higher, yet heterogeneous, degree of lipolysis than immobilized ones. The method is more suitable for small-scale lipolysis with a stirred tank to produce technical grade fatty acid.

The fourth paper, written by S. Kartohardjono, N. Saksono, D. Supramono and P. Prawati, studies the $\mathrm{NO}_{\mathrm{x}}$ have to be reduced from flue gas through absorption, using a mixture of $\mathrm{H}_{2} \mathrm{O}_{2}$ and $\mathrm{HNO}_{3}$ solutions as absorbent in the membrane contactors. In the experiment, the feed gas and the absorbent were flowed in the shell side and the lumen fibers, respectively. The absorption efficiency of $\mathrm{NO}_{\mathrm{x}}$ increased with the absorbent flow rate, but decreased with the feed 
gas flow rate. An increase in the number of fibers in the membrane contactor will have an incremental effect on the amount of $\mathrm{NO}_{\mathrm{x}}$ absorbed and removal efficiency, but will have a reduced effect on the flux and overall mass transfer coefficient. The highest values of $\mathrm{NO}_{\mathrm{x}}$ removal efficiency, mass transfer coefficient and flux achieved in this study were $47 \%, 8.7 \times 10^{-5}$ $\mathrm{cm} \cdot \mathrm{sec}^{-1}$ and $3.1 \times 10^{-5} \mathrm{mmole} . \mathrm{cm}^{-2} \cdot \mathrm{sec}^{-1}$, respectively.

The fifth paper, written by I.D. Anggraini, Keryanti, M.T.A.P. Kresnowati, R. Purwadi, R. Noda, T. Watanabe and T. Setiadi, studies the design of HFM as a gas-liquid contactor and biofilm platform, and demonstrates a significant improvement in ethanol production, with the achievement of a high ethanol to acetate molar ratio (1.43) and a maximum ethanol concentration $(1.09 \mathrm{~g} / \mathrm{L})$ three times higher than that produced in STR without HFM support $(0.35 \mathrm{~g} / \mathrm{L})$. The application of HFM for bioethanol production via syngas fermentation is an innovative approach that offers a reduction in the CO-mass transfer barrier observed in other conventional reactor designs.

The sixth paper, written by N. Saksono, R. Anditashafardiani, A.B. Junior and Y. Muharam, studies the effect of anode depth in biodiesel synthesis effectivity, in terms of the yield and specific energy of the biodiesel. The trend observed showed that the deeper the anode, the higher the yield achieved, with the highest yield achieved being $96.09 \%$ at a depth of $3.5 \mathrm{~cm}$. On the other hand, the trend of the specific energy of biodiesel also increased in line with with anode depth; at $0.5 \mathrm{~cm}$ the specific energy was $0.809 \mathrm{~kJ} / \mathrm{mL}$. Based on the level of methyl ester content, kinematic viscosity, density and acid number, this biodiesel research conforms to SNI 7182:2015. Water content conforming to SNI 7182:2015 was achieved only with the biodiesel produced at $3.5 \mathrm{~cm}$ anode depth.

The seventh paper, written by J.P. Sutikno, Z. Azizah, R. Handogo, R.A. Hikmadiyar and A. Hisyam, studies the MIMO $2 \times 2$ with Mp-GM tuning system. Four controllers were used to compare the results, namely $1 \mathrm{DoF}$ IMC, $2 \mathrm{DoF}$ IMC, decoupling $2 \mathrm{DoF}$ IMC, and inverted decoupling 2DoF IMC. The results show that inverted decoupling provides the lowest IAE value compared to the other controllers. This structure is able to reduce the interaction between variables in the MIMO $2 \times 2$ process.

The eighth paper, written by Y.N. Ma'rifah, I.F. Nata, H. Wijayanti, A. Mirwan, C. Irawan, M.D. Putra and H. Kawakita, investigates the high acid content, rich in sulfonic and biocarbon carboxylic groups of biocarbon materials, which may be easily synthesized by a one-step hydrothermal process using biocarbon from incompleted carbonization of PEFB, hydroxyethylsulfonic, acrylic and citric acid under mild conditions. The simplicity of operation, high activity and stability, low cost of the raw materials and reusability are the main features of the novelty of the biocarbon-based sulfonated solid acid catalyst, and signify that biocarbon holds great potential for green processes in various catalytic applications.

The ninth paper, written by N.N. Fathonah, T. Nurtono, Kusdianto, S. Madhania, Wahyudiono and S. Winardi, investigates the simulation configuration of MRF-RNG $k-\varepsilon$, providing realistic results to describe the hydrodynamic characteristics in an agitated tank with side-entry mixer at different impeller entry angles $(\beta)$. In quantitative analysis, at higher rotational speeds the developed circulation flow tended to be pushed further from the impeller discharge stream, as validated by the measured average velocity data. Average velocity in the tank had a tendency to increase as the impeller entry angle $\beta$ increased. The predicted average velocities were 0.0175 , 0.0197 and $0.0182 \mathrm{~m} / \mathrm{sec}$ at $\beta=0^{\circ}, 10^{\circ}$ and $15^{\circ}$, respectively, at constant rotational speed. A larger impeller entry angle $\beta$ produced a high tangential velocity, leading to a strong circulation flow.

The tenth paper, written by H. Ni'mah, R. Rochmadi, E.M. Woo, D.A. Widiasih and S. Mayangsari, studies the blend films of PLLA and glycerol with and without MA modification, 
and characterized in terms of their properties. The films showed improvement after the addition of glycerol and yet further enhancement after the addition of a compatibilizer (PLLA-g-MA). The decrease in tensile strength and Young's modulus, and the increase in elongation at break for the composite films, show that the films had become softer and more flexible. The enhanced mechanical properties were caused by the improvement in the interfacial bonding in the blend samples.

The eleventh paper, written by S. Jamilatun, Budhijanto, Rochmadi, A. Yuliestyan and A. Budiman, examines the effect of grain size, temperature, and the amount of catalyst on the characteristics of pyrolysis products from Spirulina Platensis Residue (SPR). The authors report that the use of a catalyst affects the composition of the product. A greater amount of catalyst (0-40 wt.\%) tends to result in a lower yield of bio-oil and char, with more products to be converted into the gas phase, and a fairly constant quantity of water phase obtained.

The twelfth paper, written by H.W. Aparamarta, S. Gunawan, B. Azhar, H.T. Aditya, A. Widjaja and Y.H. Ju, conducts a comparative study of batch-wise solvent extraction and the microwave-assisted extraction method for purification of triglyceride for biodiesel feedstock from crude Calophyllum Inophyllum Oil (CCIO). The authors report that a high level of purification of triglyceride (TG) was successfully obtained from crude Calophyllum inophyllum via batch-wise solvent extraction (BSE) and microwave-assisted extraction (MAE).

The thirteenth paper, written by S. Madhania, T. Nurtono, S. Winardi, Y. Muharam and W.W. Purwanto, conducts a computational study of the time-dependent flow field of a water-molasses mixture inside a stirred vessel. The authors confirm that the prediction of the volume fraction value of molasses, the density gradient, and the power number decreased as a function of time at different propeller rotational speeds in the mixing process, except for the flow number, which was reversed from the other variables.

The fourteenth paper, written by K. Kusdianto, W. Widiyastuti, M. Shimada, T. Nurtono, S. Machmudah and S. Winardi, studies the photocatalytic activity of $\mathrm{ZnO}-\mathrm{Ag}$ nanocomposites prepared by a one-step process using flame pyrolysis. The authors state that the XRD results indicate that the $\mathrm{ZnO}$ produced by flame pyrolysis had a typical hexagonal Wurtzite structure with high crystallinity, and that the crystallite size of the nanocomposites was not significantly changed by varying the Ag content.

The fifteenth paper, written by S. Machmudah, M.R. Ceaser, M.F. Alwajdy, Widiyastuti, S. Winardi, Wahyudiono, H. Kanda and M. Goto, reports on the hydrothermal and solvothermal synthesis of cerium-zirconium oxides for catalyst application. The authors indicate that ceriazirconium oxides are effective for hydrothermal delignification processes and may reduce the use of chemical compounds for the pre-treatment of wood biomass in bio-refinery applications.

The sixteenth paper, written by R. Desmiarti, A. Hazmi, Y. Trianda, Ramayandi, T. Yamada and F. Li, studies the enhancement of water treatment by combined filtration-ICPS, with integrated evaluation based on EEMS, DOC, UV260 and removal of pathogenic bacteria. The authors conclude that the combined filtration-inductively coupled plasma system is a prospective advanced technology for drinking water treatment, capable of simultaneous organic and microbial removal by filtration and degradation mechanisms.

The seventeenth paper, written by L. Qomariyah, W. Widiyastuti, S. Winardi, K. Kusdianto and T. Ogi, investigates the volume-fraction-dependent morphological transition of silica particles derived from sodium silicate. The authors report that the particle interaction in the droplets containing sol silica particles plays an important role in the formation of donut-like morphology. 
The eighteenth paper, written by A. Hamzah, S. Ainiyah, D. Ramadhani, G.E.K Parwita, Y. Rahmawati, Soeprijanto, H. Ogino and A. Widjaja, investigates the cellulases and xylanase immobilized on chitosan magnetic particles in coconut husk hydrolysis applications. The authors conclude that the immobilized cellulase and xylanase could be utilized several times without loss of activity, and that the simultaneous use of three enzymes immobilized on the chitosan magnetic particles has important economical potential for used as a biocatalyst in lignocellulose hydrolysis.

The nineteenth paper, written by M. Hawashi, H. Aparamarta, T. Widjaja and S. Gunawan, investigates the effect of solid state fermentation using Saccharomyces cerevisiae on the removal of cyanide content from cassava leaves. The authors report that the exponential decrease in cyanide content over time can lead to satisfactory detoxification in cassava leaves, with cyanide concentration reaching levels of less than 10 ppm after 60 hours of fermentation, thus providing a safe and healthy food source.

The twentieth paper, written by Mulyazmi, Wan R.W. Daud, E.D. Rahman, Purwantika, P.A. Mulya and N.G. Sari, studies the effect of operating conditions on the liquid water content flowing out of the cathode side of a PEM fuel cell, and its stability performance. The authors report that the optimal liquid water content flow occurs at a value of $90 \%$ Rha and Rhc and with a current density of $0.9 \mathrm{~mA} / \mathrm{cm}^{2}$.

We hope that this special edition of IJTech provides useful information and knowledge, and also gives new insights into the methods with which we conduct our research. We are pleased to accept and respond to any comments or enquiries that you may have regarding the direction and content of IJTech, and we invite you to join us in this venture by sending your work for future consideration.

With warmest regards from Jakarta,

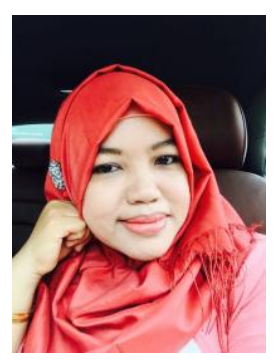

Eny Kusrini, Ph.D. Editorial Board Member

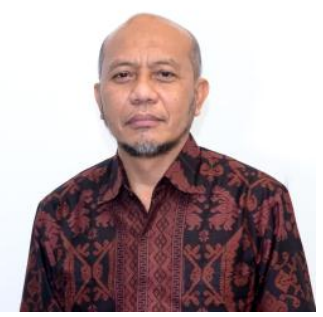

Prof. Sutrasno Kartohardjono Editorial Board Member 